\title{
Leucocyte integrin and CR1 expression on peripheral blood leucocytes of patients with rheumatoid arthritis
}

\author{
D McCarthy, M J Taylor, J Bernhagen, J D Perry, A S Hamblin
}

\begin{abstract}
Expression of the leucocyte integrins (CD11a, $b, c / C D 18)$ and of CD35 (CR1) on leucocytes from the peripheral blood of patients with rheumatoid arthritis $(\mathbf{R A})(\mathrm{n}=14)$ and control subjects $(n=12)$ was measured by flow cytometry using a rapid fixation and leucocyte preparation procedure. The mean (SE) percentages of lymphocytes expressing CD11a (RA 93.4 (1.7)\%; controls 97.2 (1.8)\%) and CD18 (RA 91.3 (2.3)\%; controls 97.0 (2.6)\%) were lower and the percentage of monocytes expressing CD11b (RA 86.9 (11.4)\%; controls 78.4 (11.9)\%) and CR1 (RA 62.6 (15.5)\%; controls $36.6(17.6) \%$ ) were higher in patients with RA than in controls. In addition, the mean fluorescence intensity of CD18 (RA 22.1 (2.3); controls $30.7(2.5)$ ) on lymphocytes was decreased and that of CD11b (RA 4.5 (0.8); controls $2.9(0.9)$ ) and CR1 (RA $2.4(0.4)$; controls $1.5(0.5)$ ) on monocytes was increased in patients with RA compared with controls. The functional importance (if any) of the altered expression of the antigens on lymphocytes is not yet known. Altered expression on monocytes is consistent with activation within the circulation.
\end{abstract}

School of

Biological Sciences,

Queen Mary and

Westfield College,

London E1 4NS,

United Kingdom

D McCarthy

J Bernhagen

Department of

Immunology,

United Medical and

Dental Schools of Guy's

and St Thomas's

Hospitals,

St Thomas's Campus,

London SE1,

United Kingdom

M J Taylor.

A S Hamblin

Department of

Rheumatology,

The Royal London

Hospital,

London E1 2AD,

United Kingdom

J D Perry

Correspondence to:

Dr D McCarthy,

School of Biological Sciences,

Queen Mary and

Westfield College,

Mile End Road,

United Kingdom.

Accepted for publication

16 April 1991
Rheumatoid arthritis (RA) is a chronic inflammatory disease characterised by infiltration of mononuclear cells into the synovium and the accumulation of leucocytes (predominantly polymorphs) in the synovial fluid of the affected joints. A crucial early event in all inflammatory responses is the localised increase in the adhesion of leucocytes to endothelial cells ${ }^{1}$ and several molecules essential to this interaction have been identified. ${ }^{23}$ On leucocytes, the best known adhesion molecules belong to the glycoprotein complex CD11/CD18 (Leu-CAM or the leucocyte integrins). ${ }^{45}$ The CD11/CD18 complex consists of $\mathrm{CD} 11 \mathrm{a} / \mathrm{CD} 18, \mathrm{CD} 1 \mathrm{lb} / \mathrm{CD} 18$, and CD1lc/CD18 which have distinct $\alpha$ chains of 175,165 , and 150 kilodaltons, respectively, but share a common $\beta$ chain of 95 kilodaltons. ${ }^{45}$ $\mathrm{CD} 11 \mathrm{a} / \mathrm{CD} 18$ is expressed on almost all leucocytes. It mediates the binding of lymphocytes to endothelial cells via their expression of ICAM 1 and ICAM $2 .{ }^{45} \mathrm{CD} 11 \mathrm{~b} / \mathrm{CD} 18$ and CD11c/ CD18 are not expressed on lymphocytes but are expressed to various extents on monocytes and polymorphs. CD11b/CD18 mediates the binding of phagocytic cells, not only to iC3b coated surfaces, but also to endothelial cells and a variety of other ligands including matrix molecules; it is probably the major adhesion molecule responsible for neutrophil-endothelial cell bind- ing and neutrophil aggregation. No ligand unique to $\mathrm{CD} 11 \mathrm{c} / \mathrm{CD} 18$ has yet been identified, but $\mathrm{CD} 11 \mathrm{c} / \mathrm{CD} 18$, like $\mathrm{CD} 11 \mathrm{~b} / \mathrm{CD} 18$, will bind to $\mathrm{iC}^{\mathrm{b}} \mathrm{.}^{45}$

Substantial amounts of CD11b/CD18 and $\mathrm{CD} 11 \mathrm{c} / \mathrm{CD} 18$ are stored in intracellular vesicles or granules in polymorphs and monocytes; little CD1la/CD18 is stored intracellularly in any leucocytes. Exposure to inflammatory cytokines or activating stimuli mobilises these intracellular reserves causing a two to twelve fold increase in the surface expression of $\mathrm{CD} 1 \mathrm{lb} / \mathrm{CD} 18$ and CD11c/CD18 on polymorphs and monocytes. ${ }^{6-9}$ As inflammatory cytokines and other activating stimuli have long been known to elicit increased adherence of leucocytes to endothelial cells, it has been suggested that increases in the expression of these integrins might be causally related to increased adhesiveness of neutrophils, ${ }^{6} 10$ although recent studies have not supported this contention. ${ }^{11-16}$

Largely from the results of in vitro studies, several mechanisms have been described which might operate in vivo to induce leucocytes to leave the circulation and enter the joints or other inflammatory foci in patients with RA. These include upregulation of integrins on leucocytes, which is supported by reports that the expression of $\mathrm{CD} 11 \mathrm{a} / \mathrm{CD} 18$ on lymphocytes from RA synovium ${ }^{17}$ and of CD11b/CD18 on polymorphs from RA synovial fluids ${ }^{18}$ is increased. As changes in the expression of integrins on circulating leucocytes before margination and emigration may be an important factor in the pathogenesis of RA, we have examined the hypothesis that the expression of components of the CD11/CD18 complex and CD35 (the complement receptor, CR1) on peripheral blood leucocytes from patients with RA may differ from that of normal control subjects. Furthermore, because it is essential to avoid increasing artefactually the expression of $\mathrm{CD} 11 \mathrm{~b} / \mathrm{CD} 18$ and $\mathrm{CD} 11 \mathrm{c} / \mathrm{CD} 18$ on monocytes and polymorphs by in vitro preparative techniques, ${ }^{6}{ }^{19}$ we have developed and used a procedure whereby leucocytes are fixed immediately ex vivo before staining their cell surface antigens for analysis by fluoresence activated cytometry.

\section{Patients and controls}

Fourteen patients (nine women, five men; mean age 54 years, age range 37-73 years) with classical or definite RA defined by the American Rheumatism Association criteria, who were being treated in the wards (six patients) or attending the outpatient rheumatology clinic (eight patients) of the Royal London Hospital 
were studied. The activity of inflammatory articular disease activity was assessed on a scale of 0 to $3(0=$ no activity, $3=$ maximum activity) by a combination of the duration of early morning stiffness, joint activity, an articular index, laboratory parameters (erythrocyte sedimentation rate, $\mathrm{C}$ reactive protein and leucocyte count), and pain score. On this basis, eight patients were classified as having grade 1 , five grade 2, and one grade 3 inflammatory disease. One patient was receiving no drugs; all of the others were receiving non-steroidal antiinflammatory drugs. In addition, five patients were receiving steroids, four penicillamine, four azathioprine, two methotrexate, and one had received gold one day before the study began. Seven patients were latex positive (titre $>1 / 80$ ), and five had extra-articular disease.

The controls were healthy subjects (two women, nine men; mean age 31 years, age range 21-50 years) who were receiving no drugs and who had no known inflammatory disease. All patients and controls gave their informed consent before the study.

\section{REAGENTS AND MATERIALS}

Dulbecco's phosphate buffered saline without calcium and magnesium ions was obtained from Oxoid (Basingstoke, Hampshire, UK) and electron microscopy grade formaldehyde from Taab (Reading, Berkshire, UK). Hanks's buffered salt solution without calcium and magnesium ions, RPMI 1640 medium and fetal calf serum were obtained from Gibco (Paisley, UK). Fluorescein labelled $F(a b)_{2}$ fragments of rabbit antimouse immunoglobulin $\mathrm{Fc}$ region were obtained from Dakopatts (Weybridge, Surrey, UK); TRIS $N$-2-hydroxyethyl-piperazine- $N$-2ethane and all other reagents, which were of AnalaR grade whenever possible, were obtained from BDH (Poole, Dorset, UK). Falcon 3911 Microtest III flexible round bottomed microtitre plates and Falcon 2054 round bottomed polystyrene tubes were obtained from Becton Dickinson (Cowley, Oxford, UK). Monoclonal antibodies were either ascites fluids which had been titrated to give a working dilution (usually $1: 1000)$ or undiluted culture supernatants (table 1).

Table 1 Monoclonal antibodies used in indirect fluorescence for cytometry

\begin{tabular}{|c|c|c|c|c|}
\hline $\begin{array}{l}\text { Monoclonal } \\
\text { antibody }\end{array}$ & $\begin{array}{l}C D \\
\text { antigen }\end{array}$ & $\begin{array}{l}\text { Cell } \\
\text { specificity }\end{array}$ & Isotype & Reference \\
\hline $\begin{array}{l}\text { PDSI* } \\
\text { BDS4* } \\
\text { W6/32† } \\
\text { 2D1† } \\
29 \neq\end{array}$ & $\begin{array}{l}- \\
\bar{Z} \\
\text { CD45 } \\
\text { CD15 }\end{array}$ & $\begin{array}{l}\text { Porcine retina (S-antigen) } \\
\text { Porcine retina (S-antigen) } \\
\text { All leucocytes (HLA, A, B, C, } \\
\text { All leucocytes } \\
\text { Polymorphs, monocytes, } \\
\text { natural killer cells }\end{array}$ & $\begin{array}{l}\text { IgG1 } \\
\text { IgG2a } \\
\text { IgG1 } \\
\text { IgG1 } \\
\text { IgM }\end{array}$ & $\begin{array}{l}20 \\
20 \\
22 \\
23 \\
24\end{array}$ \\
\hline $\begin{array}{l}\text { TG1‡ } \\
\text { UCHM1S } \\
\text { UCHT1S } \\
\text { MHM239 } \\
\text { MHM24 } \\
3.9 \ddagger\end{array}$ & $\begin{array}{l}\text { Unknown } \\
\text { CD14 } \\
\text { CD3 } \\
\text { CD18 } \\
\text { CD11a } \\
\text { CD11c }\end{array}$ & $\begin{array}{l}\text { Polymorphs, monocytes } \\
\text { Monocytes } \\
\text { T lymphocytes } \\
\text { All leucocytes } \\
\text { All leucocytes } \\
\text { Polmorphs, monocytes, }\end{array}$ & $\begin{array}{l}\text { IgM } \\
\text { IgG2a } \\
\text { IgG1 } \\
\text { IgG1 } \\
\text { IgG1 } \\
\text { IgG1 }\end{array}$ & $\begin{array}{l}24 \\
24 \\
25 \\
26 \\
26 \\
27\end{array}$ \\
\hline $44 \ddagger$ & CD11b & $\begin{array}{l}\text { Polymorphs, monocytes, } \\
\text { natural killer cells }\end{array}$ & IgGl & 28 \\
\hline E11‡ & CD35 & $\begin{array}{l}\text { Polymorphs, monocytes, } \\
\text { N lymphocytes (CRI) }\end{array}$ & IgGI & 29 \\
\hline
\end{tabular}

*Kindly provided by Dr Suleyman.

tKindly provided by Professor Bodmer.

fKindly provided by $\mathrm{Dr}$ Hogg.

SKindly provided by Professor Beverley.

† Kindly provided by Professor McMichael.
LEUCOCYTE PREPARATION, LABELLING, AND ANALYSIS

Leucocytes were prepared for labelling using a procedure developed originally for morphological analysis. ${ }^{21}$ Briefly, blood $(0.5 \mathrm{ml})$ taken from the antecubital vein was mixed immediately with $0.5 \mathrm{ml}$ of prewarmed $\left(37^{\circ} \mathrm{C}\right)$ phosphate buffered saline or Hanks's balanced salt solution with $0.01 \mathrm{~mol} / 1$ HEPES (pH 7.3) (HHBSS) containing $0.4 \%$ formaldehyde and stored for $4 \mathrm{~min}$ at $37^{\circ} \mathrm{C}$. A $20 \mathrm{ml}$ portion of $0.155 \mathrm{~mol} / 1$ ammonium chloride buffered with $0.01 \mathrm{~mol} / \mathrm{l}$ TRIS chloride or $0.01 \mathrm{~mol} / \mathrm{l}$ HEPES (pH 7.3) was added, and when the erythrocytes had lysed (2-4 minutes at $37^{\circ} \mathrm{C}$ or $8-12$ minutes at $20^{\circ} \mathrm{C}$ ), the leucocytes were collected by centrifuging for 5 minutes at $200 \mathrm{~g}$, washed twice by centrifuging for 10 minutes at $200 \mathrm{~g}$ in phosphate buffered saline or Hanks's balanced salt solution (first $20 \mathrm{ml}$, then $10 \mathrm{ml}$ at $0^{\circ} \mathrm{C}$ ), resuspended in $0.5 \mathrm{ml}$ of phosphate buffered saline and stored at $0^{\circ} \mathrm{C}$. Cell samples $(25 \mu \mathrm{l})$ were labelled within two hours. Incubations were performed in a microtitre plate at $0^{\circ} \mathrm{C}$ using 30 minute periods and the cells were washed after each incubation with $100 \mu \mathrm{l}$ of medium. RPMI containing $5 \%$ fetal calf serum was used as the medium throughout.

Control cells were prepared which were either incubated with mouse monoclonal antibody alone or with a subclass matched irrelevant monoclonal antibody (PDS1 or BDS4). Fluorescein conjugated rabbit antimouse $\mathrm{Fc} F(\mathrm{ab})_{2}$ diluted 1:50 was used as the second layer. Labelled cells were resuspended in $25 \mu \mathrm{l}$ of RPMI containing $5 \%$ fetal calf serum, transferred to round bottomed polystyrene tubes containing $1 \%$ paraformaldehyde, left for two hours in the dark at $4^{\circ} \mathrm{C}$ and analysed by flow cytometry using a FACscan (Becton Dickinson, Mountain View, CA, USA) equipped with Consort 30 software (Hewlett Packard). Polymorphs, monocytes, and lymphocytes were separated on the basis of their forward and side scatter; their identity and purity were established by staining with monoclonal antibodies which identify leucocytes (W6/32 and 2D1), and leucocyte subpopulations (29, TG1, UCHM1 and UCHT1). Fluorescence data were collected on a four decade logarithmic scale. Markers were set on the control antibody, which was PDS1 for monocytes and lymphocytes and UCHT1 for polymorphs because of the unusually high non-specific binding of PDS1 by polymorphs. There was generally less than $5 \%$ nonspecific staining. The percentage of fluorescent cells was calculated by subtracting the negative control values from the total in each instance. The mean fluorescence intensity ratio was calculated by dividing the mean fluorescence intensity ratio of a leucocyte population labelled with a given monoclonal antibody by the mean fluorescence intensity ratio of the same population labelled with the negative control antibody.

\section{STATISTICAL ANALYSES}

ANOVA and the Mann Whitney rank sum test for unpaired data were used to compare data from patients with RA and controls; the two procedures gave essentially similar results. All 
calculations, correlations, and multiple regression analyses were performed using the 'number cruncher' statistical package on a personal computer; statistical significance was accepted when $\mathrm{p}<0.05$.

\section{Results}

The intersubject variation in the proportion of cells expressing a particular surface marker varied greatly among the different markers and leucocyte types. However, figs 1-3 show that the ranges for any given marker and cell type were largely similar for patients with RA and controls, with the exception that the medians for the percentage of lymphocytes expressing CD1la and CD18 were smaller and those for the percentage of monocytes expressing $\mathrm{CD} 1 \mathrm{lb}$ and CR1 were higher in patients with RA than in controls (figs 1 and 2).

Similarly, the intersubject variation in the values found for the mean fluorescence intensity ratio of a particular surface marker differed greatly among the various markers and leucocyte types. Figures 4-6 show that, again, the ranges for any given marker and cell type were largely similar for patients with $\mathrm{RA}$ and controls. However, the median value of the mean fluorescence intensity ratio for $\mathrm{CD} 18$ on lymphocytes was decreased and that for CD11b and CR1 on monocytes were increased in patients with RA compared with controls (figs 4 and 5).

Evidence suggesting that a given $\alpha$ chain might be expressed at similar relative levels on different leucocyte types within patients, was found only for CDIla on lymphocytes and polymorphs in control subjects and for CD11b and CDIlc on monocytes and polymorphs in controls and patients with RA (table 2). Conversely, evidence suggesting that, within subjects, the different $\alpha$ chains might be expressed at similar relative levels on given leucocyte types, was found only for CD11a and CD11b on control monocytes, RA lymphocytes, and RA monocytes, and for CD1lb and CD1lc on control and RA monocytes (table 3).

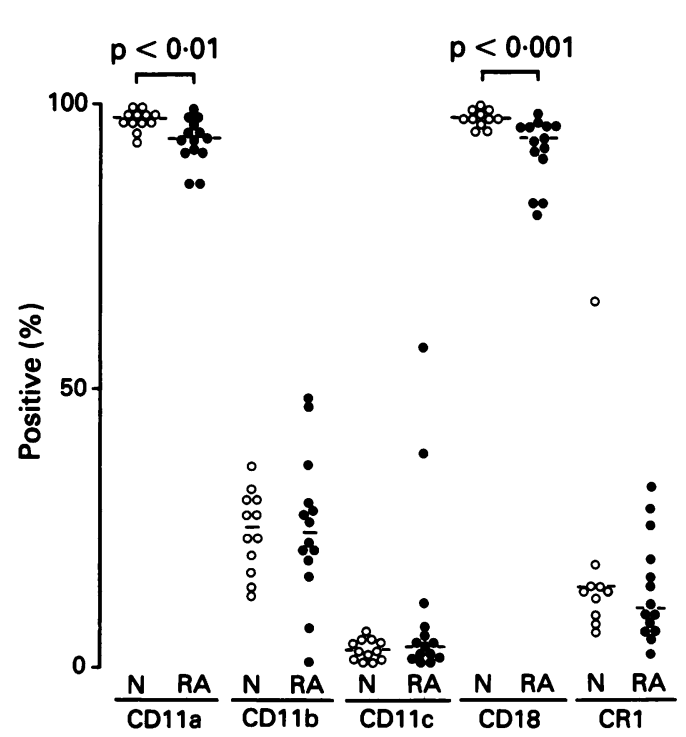

Figure 1 Percentage of lymphocytes which express $C D 11 / C D 18$ and $C R 1$. N= control subjects, $R A=$ patients with rheumatoid arthritis. Bars indicate median values.

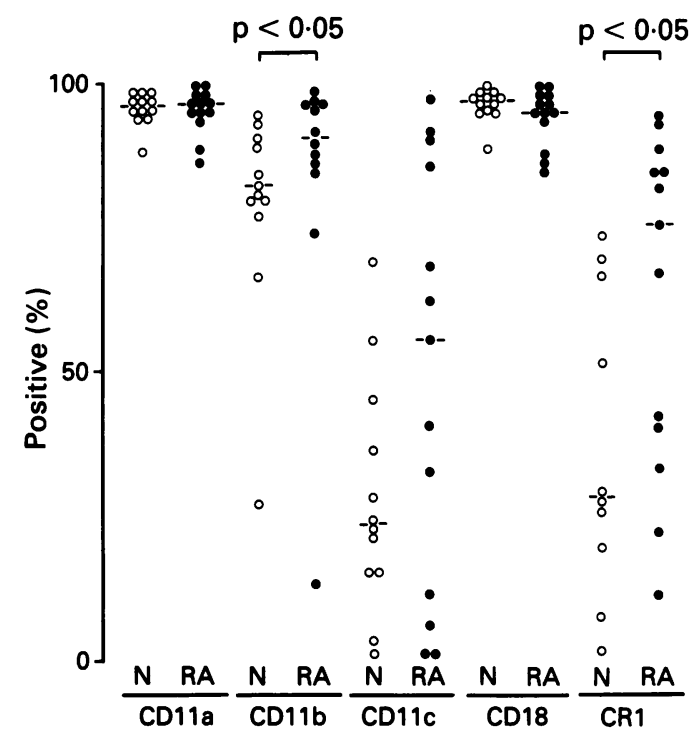

Figure 2 Percentage of monocytes which express $C D 11 / C D 18$ and $C R 1$. $N=$ control subjects, $R A=$ patients with rheumatoid arthritis. Bars indicate median values.

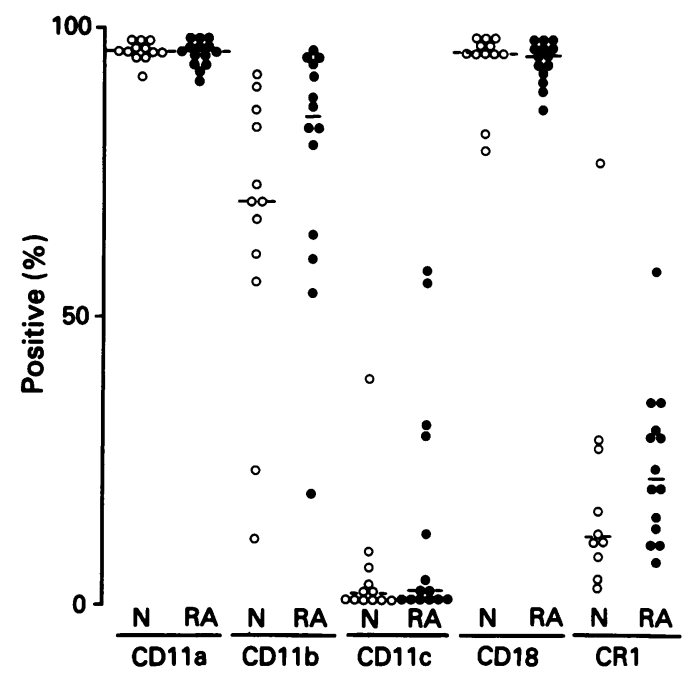

Figure 3 Percentage of polymorphs which express $C D 11 / C D 18$ and $C R 1$. $N=$ control subjects, $R A=$ patients with rheumatoid arthritis. Bars indicate median values.

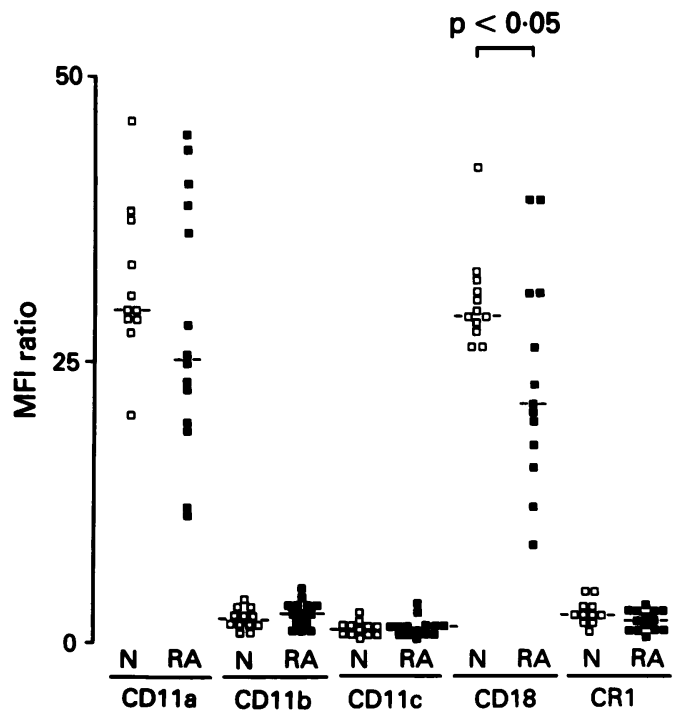

Figure 4 Mean fluorescence intensity ratios of $C D 11 / C D 18$ and $C R I$ on lymphocytes from control subjects $(N)$ and patients with rheumatoid arthritis $(R A)$. Bars indicate median values. 


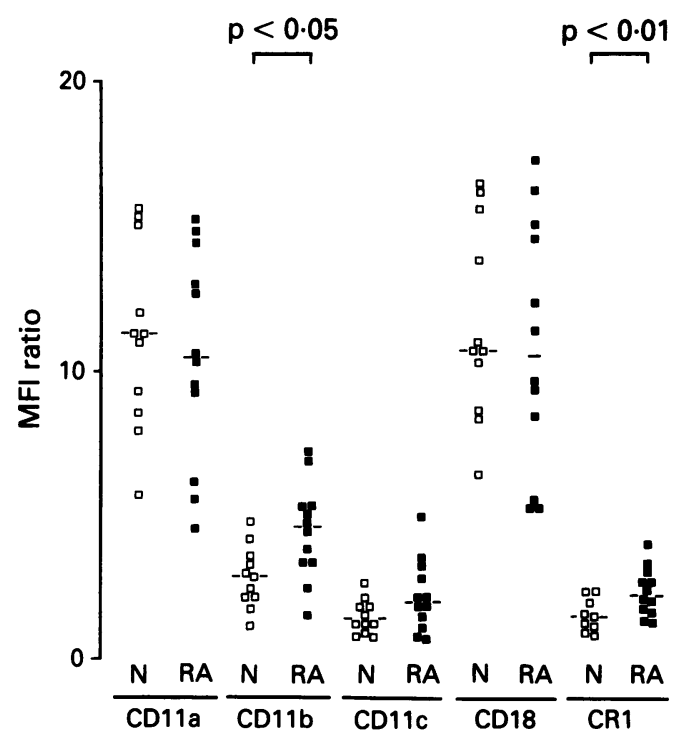

Figure 5 Mean fluorescence intensity ratios of CD11/CD18 and $C R 1$ on monocytes from control subjects $(N)$ and patients with rheumatoid arthritis $(R A)$. Bars indicate median values.

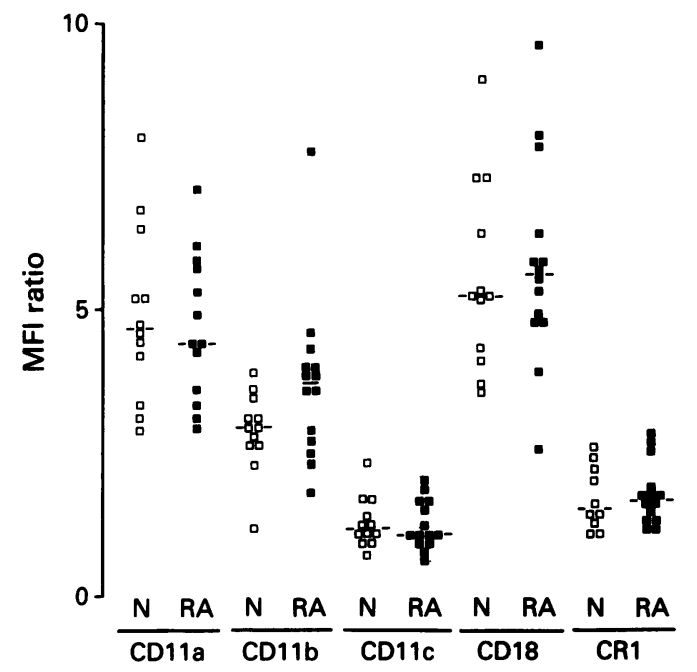

Figure 6 Mean fluorescence intensity ratios of CD11/CD18 and $C R 1$ on polymorphs from control subjects $(N)$ and patients with rheumatoid arthritis $(R A)$. Bars indicate median values.
When neutrophils are activated in vitro the surface expression of CR1 and CR3 (CD11b/ CD18) increases in parallel. ${ }^{30}$ Possible correlations between the mean fluorescence intensity ratio of CR1 and the mean fluorescence intensity ratios of the components of the CD11/CD18 complex were therefore analysed. The results showed that on control and RA polymorphs, the mean fluorescence intensity ratio of CR1 was correlated only with that of $\mathrm{CD} 18$, whereas on control monocytes it was correlated with the mean fluorescence intensity ratios of all components of the CD11/CD18 complex and on RA monocytes with the mean fluorescence intensity ratios of CD1la, CD11b and CD18 (table 4). No significant correlations were found between the mean fluorescence intensity ratios of CR1 and those of the CD11/CD18 complex on lymphocytes from either patients with RA or controls (not shown).

Inflammatory disease activity amongst the patients with RA was correlated with the percentage of polymorphs expressing CD1lc $(p<0.0005)$, with the percentages of monocytes expressing CR1 $(p<0.05)$ and CD1 $1 c(p<0.005)$, with the mean fluorescence intensity ratio of CD1lc on polymorphs $(p<0.05)$ and with the mean fluorescence intensity ratios of $\mathrm{CD} 18$ $(\mathbf{p}<0.05)$, CD1lc $(\mathbf{p}<0.01)$, and CD11b $(p<0.05)$ on monocytes (Spearman's rank correlations and two tailed $t$ tests with $\mathrm{p}$ values unadjusted for the number of correlations sought). The numbers of circulating lymphocytes, monocytes, and polymorphs in controls and patients with RA were not significantly correlated with either the percentage of cells expressing any of the markers analysed, or the mean fluorescence intensity ratios of those markers.

\section{Discussion}

The rapid leucocyte fixation and preparation procedure that was used in these studies was designed specifically to prevent in vitro changes in the surface expression of the leucocyte intergrins. Brief fixation with formaldehyde is known to inhibit the changes in neutrophil

Table 2 Correlations found between the expression of components of the CDI1/CD18 complex on different types of leucocytes from patients with $R A$ and controls

\begin{tabular}{|c|c|c|c|c|c|}
\hline \multirow[t]{2}{*}{ « Chain } & \multirow[t]{2}{*}{ Leucocytes compared } & \multicolumn{2}{|c|}{ Control subjects } & \multicolumn{2}{|c|}{ Patients with $R A$} \\
\hline & & $r$ & $p$ Value & $r$ & pValue \\
\hline $\begin{array}{l}\text { CD11a } \\
\text { CD11b } \\
\text { CD11c }\end{array}$ & $\begin{array}{l}\text { Lymphocytes } \times \text { polymorphs } \\
\text { Monocytes } \times \text { polymorphs } \\
\text { Monocytes } \times \text { polymorphs }\end{array}$ & $\begin{array}{l}0.614 \\
0.680 \\
0.642\end{array}$ & $\begin{array}{l}0.034 \\
0.021 \\
0.033\end{array}$ & $\begin{array}{l}\overline{0.609} \\
0.607\end{array}$ & $\begin{array}{l}\overline{0.035} \\
0.036\end{array}$ \\
\hline
\end{tabular}

Unlisted combinations of leucocytes and those for which values are not indicated $(-)$ had correlation coefficients $(r)$ less than 0.563 and $p$ values greater than 0.05 . p Values are unadjusted for the number of comparisons made.

Table 3 Correlations found between the expression of different components of the CDI1/CD18 complex on leucocytes from patients with $R A$ and controls

\begin{tabular}{|c|c|c|c|c|c|}
\hline \multirow[t]{2}{*}{ Leucocytes } & \multirow[t]{2}{*}{ a Chains compared } & \multicolumn{2}{|c|}{ Control subjects } & \multicolumn{2}{|c|}{ Patients with $R A$} \\
\hline & & $r$ & $p$ Value & $r$ & p Value \\
\hline $\begin{array}{l}\text { Lymphocytes } \\
\text { Monocytes } \\
\text { Monocytes }\end{array}$ & 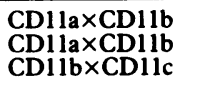 & $\begin{array}{l}\overline{0.819} \\
0.824\end{array}$ & $\begin{array}{l}\overline{0.002} \\
0.002\end{array}$ & $\begin{array}{l}0.780 \\
0.744 \\
0.590\end{array}$ & $\begin{array}{l}0.001 \\
0.006 \\
0.043\end{array}$ \\
\hline
\end{tabular}


Table 4 Correlations found between the mean fluorescence intensity ratios of the components of the CD11/18 complex and the mean fluorescence intensity ratio of $C R I$ on leucocytes from patients with $R A$ and controls

\begin{tabular}{|c|c|c|c|c|c|}
\hline \multirow[t]{2}{*}{ Leucocytes } & \multirow[t]{2}{*}{ Markers compared } & \multicolumn{2}{|c|}{ Controls } & \multicolumn{2}{|c|}{ Patients with $R A$} \\
\hline & & $r$ & p Value & $r$ & $p$ Value \\
\hline $\begin{array}{l}\text { Polymorphs } \\
\text { Monocytes } \\
\text { Monocytes } \\
\text { Monocytes } \\
\text { Monocytes }\end{array}$ & $\begin{array}{l}\mathrm{CD} 18 \times \mathrm{CR} 1 \\
\mathrm{CD} 11 \mathrm{a} \times \mathrm{CR} 1 \\
\mathrm{CD1} 1 \mathrm{~b} \times \mathrm{CR} 1 \\
\mathrm{CD} 1 \mathrm{c} \times \mathrm{CR} 1 \\
\mathrm{CD} 18 \times \mathrm{CR} 1\end{array}$ & $\begin{array}{l}0.650 \\
0.899 \\
0.777 \\
0.699 \\
0.832\end{array}$ & $\begin{array}{l}0.042 \\
0.001 \\
0.014 \\
0.036 \\
0.005\end{array}$ & $\begin{array}{l}0.621 \\
0.677 \\
0.686 \\
0.828\end{array}$ & $\begin{array}{l}0.018 \\
0.016 \\
0.014 \\
-\quad \\
0.001\end{array}$ \\
\hline
\end{tabular}

Unlisted combinations of markers and leucocytes and those for which no values are indicated (-), all had correlation coefficients ( $r$ ) less than $0 \cdot 605$ and p values greater than $0 \cdot 05$. p Values are unadjusted for the number of comparisons made.

shape which accompany activation ${ }^{21}$ and to preserve the expression of leucocyte surface markers such as CD3, CD4, CD8, and major histocompatibility complex class II (Hamblin et $a l$, unpublished data). Thus, except for any possible changes due to the process of venepuncture itself, we believe that our findings represent the true state of these molecules on the surface of leucocytes from the circulating pool.

Our results show considerable intersubject variation in the expression of CR1 and the components of the CD11/CD18 complex, but are nevertheless broadly consistent with previous findings for normal subjects. ${ }^{45173132} \mathrm{CD} 1 \mathrm{la} /$ CD18 was expressed on all lymphocytes, monocytes, and polymorphs (figs 1-3), but the level of expression varied from subject to subject (figs 4-6). The percentages of cells expressing CD1lb and CDIlc varied greatly and the median values were always lower than those for CD11a (figs 1-3). These results are consistent with CD11b and CD11c being weakly expressed on leucocytes.

As yet, the mechanisms which regulate the expression of integrins on leucocytes and which presumably contribute to the substantial intersubject variations in expression are only partly understood. To the best of our knowledge, the correlations noted in tables $2-4$ have not previously been reported elsewhere and the biological phenomena responsible for these must be largely a matter for speculation. The fact that similar relative amounts of $C D 11 b$ and CD1lc were expressed on monocytes and polymorphs from the same subject, irrespective of whether they were patients or controls (table 2), is consistent with the expression of these integrins being upregulated on the two cell types in response to activating agents encountered in the circulation. The relative parity in expression of certain combinations of integrins on lymphocytes and monocytes (table 3) may be due to intersubject variations in other mechanisms which regulate coordinately the expression of different integrins-for example, those which control integrin biosynthesis during leucocyte differentiation.

Although the surface expression of CR1 and CR3 (CD11b/CD18) on neutrophils is known to increase in parallel on stimulation, ${ }^{33}$ we found no significant correlation between the mean fluorescence intensity ratios of those markers on either control or RA polymorphs. In fact, the mean fluorescence intensity ratio of $\mathrm{CR} 1$ seemed better correlated with that of $\mathrm{CD} 18$ on polymorphs from the two subject groups (table 4). Interestingly, with the exception of CD1lc on cells from patients with RA, the mean fluorescence intensity ratio of CR1 on monocytes was correlated with each of the components of the CD11/CD18 complex on monocytes from patients with RA and controls (table 4); however, the biological significance of this previously unreported relation is yet to be explained.

Clear but small decreases in the percentage of RA lymphocytes expressing CD11a and CD18 relative to controls were found (fig 1). These results contradict directly an earlier report, ${ }^{17}$ in which no difference in the expression of CDIla on RA lymphocytes was found. Larger, but statistically less significant increases, occurred in the percentages of RA monocytes expressing CR1 (fig 2), which, if taken together with similarly significant increases in the mean fluorescence intensity ratios of CR1 and CD11b on these cells (fig 5), is suggestive of previous activation in vivo. The mean fluorescence intensity ratio of $\mathrm{CD} 1 \mathrm{lb}$ was also increased on monocytes from patients with diabetes, but unfortunately the cells were not also examined for CR1. ${ }^{34}$ Our results also differ from those of Heurkens $e t a l^{35}$ who found that RA monocytes expressed significantly less CR1 than control monocytes. Except for a difference in experimental technique (radiolabelling versus fluorescence activated cytometry) there is no obvious explanation for this discrepancy. As increases in the expression of CR1 and/or CD1lb have been noted on neutrophils from patients with other inflammatory conditions, such as mild burns, ${ }^{36}{ }^{37}$ haemodialysis induced neutropenia, ${ }^{38}$ and systemic lupus erythematosus, ${ }^{39}$ it was perhaps surprising that similar increases were not found on RA neutrophils, especially as RA neutrophils show other evidence of activation in vivo $^{40}$ and chemotaxin induced quantitative increases in CD11b/CD18 expression precede the qualitative changes that seem to be essential for increased adherence. However, patients with severe burns show a decrease in the percentage of CR1 positive neutrophils and those who develop bacteraemia or pneumonia show a marked reduction in the percentage and absolute numbers of CD1lb positive neutrophils. ${ }^{37}$ Non-steroidal anti-inflammatory drugs and second line drugs might be expected to affect integrin expression, but no strong conclusions regarding the effects of drugs could be drawn because the number of patients receiving any particular drug or combination of drugs was so small (between one and three). Nonetheless, it is interesting that the only patient receiving no drugs (inflammatory disease activity grade 2) was among the 10 percentile with the lowest mean fluorescence intensity ratios for CD1la, 
CD11b, CD11c, and CD18 on lymphocytes and among the 10 percentile with the highest mean fluorescence intensity ratios for CR1 on lymphocytes and for CD11b, CD11c, CD18, and CR1 on monocytes and polymorphs. It is also noteworthy first, that correlations between CR1 and $\mathrm{CD} 11 / \mathrm{CD} 18$ expression and disease activity (see text) and between CR3 (CD11b/CD18) expression and neutrophil polarisation ${ }^{41}$ all involve cell surface antigens that are known to be upregulated by inflammatory stimuli, and second, that they were observed despite the fact that most patients were receiving antiinflammatory drugs.

In summary, these studies did not show the marked changes in CRl or integrin expression on RA polymorphs which might have been expected. However, substantial changes were seen in RA monocytes that were consistent with previous activation in vivo.

We are grateful to Dr P Thompson for permission to study some of his patients, to Fran Pegley, Sarah Pearson and the staff of Hastings Ward (London Hospital, Mile End) for clinical assistance, to the subjects who gave blood for these studies, to Dr N Hogg and A K Brown for valuable discussions, to Dr J Deeks for statistical advice, and to Mrs J Smith, Miss S Maguire, and Mrs R Graham for typing the manuscript. Professor PC L Beverley (University College Hospital, London), Professor $\mathrm{W}$ Bodmer and Dr N Hogg (Imperial Cancer Research Fund, London), Professor A J McMichael (Radcliffe Hospital, Oxford), and Dr S Suleyman (St Thomas's Hospital, London) are thanked for providing the monoclonal antibodies.

1 Patarroyo $M$, Makgoba $M$ W. Leucocyte adhesion to cells in immune and inflammatory responses. Lancet 1989; $1139-42$.

2 Hynes R O. Integrins: a family of cell surface receptors. Cell 1987; 48: 549-54.

3 Kornblihtt A R, Gutman A. Molecular biology of the extracellular matrix proteins. Biol Rev 1988; 63: 465-507.

4 Hogg N. The leucocyte integrins. Immunol Today 1989; 10: $111-4$

5 Arnaout $M$ A. Structure and function of the leucocyte adhesion molecules CD11/CD18. Blood 1990; 75: 1037-50.

6 Miller L J, Bainton D F, Borregaard N, Springer T A. Stimulated mobilisation of monocyte Mac-1 and p150,95 adhesion proteins from an intracellular vesicle compartment to the cell surface. $\mathcal{F}$ Clin Invest 1987; 80: 535-44.

7 Pichyangkul S, Schick D, Schober W, Dixon G, Khan A. Increased expression of adhesive proteins on leukocytes by TNF $\alpha$. Exp Hematol 1988; 16: 588-93.

8 Freyer D R, Morganroth M L, Rogers C E, Arnaout M A, Todd R F. Modulation of surface CD11/CD18 glycoproteins (Mol, LFA-1, p150,95) by human mononuclear phagocytes. Clin Immunol Immunopathol 1988; 46: 272-83.

9 Harlan J M, Killen P D, Senecal F M, et al. The role of neutrophil membrane glycoprotein gp-150 in neutrophil neutrophil membrane glycoprotein gp-150 in neutrophi
adherence to endothelium in vitro. Blood 1985; 66: 167-78.

10 Anderson D C, Miller L J, Schmalstieg F C, Rothlein R, Springer T A. Contributions of the Mac-1 glycoprotein family to adherence-dependent granulocyte functions: structure-function assessments employing subunit-specific monoclonal antibodies. I Immunol 1986; 137: 15-27.

11 Philips M R, Buyon J P, Winchester R, Weissmann G, Abramson S B. Up-regulation of the iC3b receptor (CR3) is neither necessary nor sufficient to promote neutrophil aggregation. I Clin Invest 1988; 82: 495-501.

12 Vedder N B, Harlan J M. Increased surface expression of $\mathrm{CD} 1 \mathrm{lb} / \mathrm{CD} 18$ (Mac-1) is not required for stimulated neutrophil adherence to cultured endothelium. $\mathcal{I}$ Clin Invest 1988; 81: 676-82.

13 Zimmerman A, McIntyre T M. Neutrophil adherence to human endothelium in vitro occurs by $\mathrm{CDw} 18$ (Mol MAC-1/LFA-1/GP150,95) glycoprotein-dependent and -independent mechanisms. $f$ Clin Invest 1988; 81: 531-7.

14 Schleiffenbaum B, Moser R, Patarroyo M, Fehr J. The cell surface glycoprotein Mac-1 (CD11b/CD18) mediates neutrophil adhesion and modulates degranulation independently of its quantitative cell surface expression. $\mathcal{I}$ I mmunol 1989; 142: 3537-45

15 Schwarz B R, Harlan J M. Neutrophil membrane sulphydryl groups are involved in stimulated neutrophil adherence to endothelium. I Leukoc Biol 1989; 45: 177-82.

16 Tonnensen M G, Anderson D C, Springer T A, Knedler A Avdi N, Henson P M. Adherence of neutrophils to cultured human microvascular endothelial cells: stimulation by chemotactic peptides and lipid mediators and dependence upon the Mac-1, LFA-1, p150,95 glycoprotein family. f Clin Invest 1989; 83: 637-46.

17 Cush J J, Lipsky P E. Phenotypic analysis of synovial tissue and peripheral blood lymphocytes isolated from patients with rheumatoid arthritis. Arthritis Rheum 1988; 31: $1230-8$.

18 Emery P, Lopez A F, Burns G F, Vadas M A. Synovial fluid neutrophils of patients with rheumatoid arthritis have membrane antigen changes that reflect activation. Ann Rheum Dis 1988; 47: 34-9.

19 Fearon D T, Collins L A. Increased expression of C3b receptors on polymorphonuclear leukocytes induced by chemotactic factors and by purification procedures. FImmunol 1983; 130: 370-5.

20 Banga J P, LeRoy F, Suleyman S, Kasp E, Brown E Dumonde $\mathbf{D}$. Analysis of antigenic determinants of retina S-antigen with monoclonal antibodies. Invest Ophthalmo Vis Sci 1988; 29: 12-21.

21 McCarthy D A, Bernhagen J, Liu-Y-C, Perry J D. A rapid preparation technique for leucocytes. $\mathcal{F}$ Microsc 1990; 158 : 63-72.

22 Barnstaple C J, Bodmer W F, Brown G, et al. Production of monoclonal antibodies to group A erythrocytes, HLA and other human cell surface antigens-new tools for genetic analysis. Cell 1978; 19: 9-20.

23 Pizzolo G, Sloane J, Beverley P, et al. Differential diagnosis of malignant lymphoma and nonlymphoid tumours using monoclonal anti-leucocyte antibody. Cancer 1980; 46: 2640-7.

24 Hogg N, MacDonald S, Slusarenko M, Beverley P C L. Monoclonal antibodies specific for human monocytes, granulocytes and endothelium. Immunology 1984; 53: 753-67.

25 Beverly P C C, Callard R E. Distinctive functional characteristics of human ' $T$ ' lymphocytes defined by $E$ rosetting or a monoclonal anti-T cell antibody. Eur 7 I mmunol 1981; or a monocion.

26 Hildreth J E K, Gotch F M, Hildreth P D K, McMichael A J. A human lymphocyte associated antigen involved in cellmediated lympholysis. Eur f Immunol 1983; 13: 202-8.

27 Hogg N, Takacs L, Palmer D G, Selvendran Y, Allen C. The p150,95 molecule is a marker of human mononuclear phagocytes: comparison with expression of class II molecules. Eur f Immunol 1986; 16: 240-8.

28 Malhotra V, Hogg N, Sim R B. Ligand binding by the p150, 95 antigen of U937 monocytic cells; properties in common with complement receptor type 3 (CR3) Eur $\mathcal{J}$ Immunol 1986; 16: 1117-23.

29 Hogg N, Ross G D, Jones D B, Slusarenko M, Walport M J, Lachmann $P$ J. Identification of an anti-monocyte monoclonal antibody that is specific for membrame complement receptor type one (CR1). Eur I Immunol 1984; 14: 236-43.

30 O'Shea J J, Brown E J, Seligmann B E, Metcalf J A, Frank $M \mathrm{M}$, Gallin J I. Evidence for distinct intracellular pools of receptors for $\mathrm{C} 3 \mathrm{~b}$ and $\mathrm{C} 3 \mathrm{bi}$ in human neutrophils. FImmunol 1985; 134: 2580-7.

31 Nelson R D, Hasslen S R, Ahrenholz D H, Halls E, Solem $L \mathrm{D}$. Influence of minor thermal injury on expression of complement receptor $\mathrm{CR} 3$ on human neutrophils. $\mathrm{Am} \mathcal{f}$ Pathol 1986; 125: 563-70.

32 Anderson D C, Freeman K L B, Heerdt B, Hughes B J, Jack $R$ M, Smith $C$ W. Abnormal stimulated adherence of neonatal granulocytes: impaired induction of surface Mac-1 by chemotactic factors or secretagogues. Blood 1987; 70: $740-50$.

33 Van Epps D E, Bender J G. Simpson S J, Chenoweth D E. Relationship of chemotactic receptors for formyl peptide and C5a to CR1, CR 3 and Fc receptors on human neptrophils. $\exists$ Leukoc Biol 1990; 47:519-27.

34 Setiadi H, Wautier J-L, Courbillon-Mallet A, Passa P, Caen J. Increased adhesion to fibronectin and Mo-1 expression by diabetic monocytes. F Immunol 1987; 138: 3230-4.

35 Heurkens A H M, Breedveld F C, Keur C V D, Brand R, Daha M R. Degradation of aggregates of activated C3 (C3b) by monocytes of patients with rheumatoid arthritis related to vasculitis. Clin Exp Immunol 1990; 80: 177-80.

36 Moore F D, Davis C, Rodrick M, Mannick J A, Fearon D T. Neutrophil activation in thermal injury as assessed by increased expression of complement receptors. $N$ Engl ff Med 1986; 314: 948-53.

37 Babcock G F, Alexander J W, Warden G D. Flow cytometric analysis of neutrophil subsets in thermally injured patients developing infection. Clin Immunol Immunopathol 1990; 54: $117-25$.

38 Arnaout M A, Hakim R M, Todd R F, Dana N, Colten H R. Increased expression of an adhesion-promoting surface of glycoprotein in the granulocytopenia of haemodialysis. NEnglf Med 1985; 312: 457-62.

39 Buyon J P, Shadick N, Berkman R, et al. Surface expression of Gp 165/95, the complement receptor CR3, as a marker of . Clin Immunol Immunopathol 1988; 46: 141-9.

40 Brown $\mathrm{K}$ A. The polymorphonuclear cell in rheumatoid arthritis. Brf Rheumatol 1988; 29: 150-5.

41 McCarthy D A, Bernhagen J, Taylor M J, et al. Morphological evidence that activated polymorphs circulate in the peripheral blood of patients with rheumatoid arthritis. Ann Rheum Dis 1992; 51: 13-18. 